\title{
The great divide: 'ruralisation' of poverty in Russia
}

\author{
Christopher J. Gerry, Eugene Nivorozhkin and John A. Rigg ${ }^{\star}$
}

\begin{abstract}
Using data from the Russian Longitudinal Monitoring Survey for the period 20002004 we investigate poverty trends in Russia. We find that urban poverty declines at twice the rate of rural poverty so that by 2004 poverty in Russia had become a largely rural phenomenon for the first time since transition began. This finding does not stem from changing population characteristics or shares, is not dependent on the use of a particular poverty line nor is it driven by the rapid expansions that have occurred in Moscow, St Petersburg or other urban areas. Our findings flesh out those of Ravallion and colleagues, who, in contrast to other regions, 'find signs' of a ruralisation of poverty in Eastern Europe and the former Soviet Union. We attribute some of the differential to the labour market.
\end{abstract}

Key words: Russia, Poverty, Urban, Rural, RLMS

FEL classifications: I31, I32, P25, P46, O18

\section{Introduction}

Any visitor arriving at Sheremetyevo airport, and enduring the bumper-to-bumper journey from the surrounding countryside to downtown Moscow cannot fail to notice the change of scenery as the city centre beckons. From birch forests dotted with village style wooden houses, through large and brand new luxury hotels, shopping malls and leisure complexes and on to Mercedes dealerships; the level of visible wealth increases as the Kremlin nears. The picket fences and decaying huts of rural Moscow are soon forgotten as one of Europe's biggest, richest and most booming cities bursts into view. Since the dark days of Russia's 1998 financial crisis, economic growth has been impressive in both its breadth and persistence and has prompted a dramatic decline in the incidence of poverty for all socioeconomic groups. ${ }^{1}$ So, how misleading are first impressions? How thinly spread is the enormous wealth generated by Russia's recent resource-driven boom? Are there pockets of the population excluded from the benefits of this growth? Focusing in particular on the rural-urban dimension, these are among the questions we address in this paper.

Manuscript received 30 April 2007; final version received 5 November 2007.

Address for correspondence: Christopher J. Gerry, UCL School of Slavonic and East European Studies, Gower Street, London, WC1E 6BT, UK. E-mail: c.gerry@ucl.ac.uk

^University College London, UK; University College London, UK; and London School of Economics, respectively.

${ }^{1}$ Cumulative economic growth between 1999 and 2003 was $37.5 \%$ and official poverty rates fell from $28.3 \%$ to $20.6 \%$ (World Bank, 2005, 2006). According to other methodologies (see World Bank, 2005) 'Russia succeeded in cutting poverty in half between 1999 and 2002, from 41.5 percent in 1999 to 19.6 percent in 2002. About 30 million people have escaped poverty in this period'.

(C) The Author 2008. Published by Oxford University Press on behalf of the Cambridge Political Economy Society. All rights reserved. 


\section{2 of 15 C. J. Gerry, E. Nivorozhkin and J. A. Rigg}

Our analysis goes beyond the well-documented observation of the divergent poverty experiences of rural and urban dwellers by differentiating among settlements of different size. We show, using more recent data than previously, that the relative gap between different population sub-groups has grown dramatically since the 1998 financial crisis.

The idea of economic growth as the most effective means of poverty reduction is not new. Over four decades have passed since J. F. Kennedy, in 1963, referred to economic growth as the 'rising tide that lifts all boats'. A recent World Bank study (2005) declared that Russian growth, subsequent to the 1998 crisis, has been 'pro-poor', prompting optimism that the (2002) goal of cutting poverty in half by 2007 is achievable. Notwithstanding these positive comments, that same World Bank report talks of 'deep pockets of poverty that may be resilient to benefiting from general economic improvements' and characterises these pockets as being populated by the less educated, unemployed, rural and young. If this is so and Russia's rising economic tide is having unequal effects it is essential, from a social justice (as well as economic efficiency) perspective, that policy makers understand the nature, cause and impact of such inequalities. While there is an expanding literature on the recent period of economic growth in Russia and several studies have documented its impact on the poor, much less attention has been focused on the extent to which different population groups have experienced the economic recovery.

While the majority of studies concur that rural poverty is greater than urban poverty, ${ }^{1}$ there are few papers that speak directly to this rural-urban divide and none that explicitly discuss the growing divergence. Wegren et al. (2003) argue that a part of Russia's rural poverty can be attributed to 'urban bias'2 but that it is also necessary to understand (i) the human capital and demographic composition of those in poverty (structural), (ii) the economic opportunities exploited by rural households (behavioural) and (iii) psychological factors (psychological). They find that poor rural households have lower levels of human and productive capital, they do not exploit land use opportunities and have developed more negative psychological dispositions. While these findings are important they do not shed light on the growing rural-urban differentials.

In their rural/urban comparisons based on surveys in the cities of Achit and Yekaterinburg, Pickup and White (2003) find that new private sector opportunities are more common in urban areas and that more educated individuals are better placed to exploit them. Nevertheless, in both rural and urban areas there remains widespread reliance on home production and kin networks to insure oneself against poverty.

Taking a broader set of transition countries, Katsiaouni and Gorniak (2001) conclude that rural poverty has its own dimensions related specifically to an ageing rural population investing less resources in the accumulation of human capital and thus propagating a rural economy characterised by fewer jobs, lower skill levels and less occupational diversity. Using the Russian Longitudinal Monitoring Survey (RLMS) to investigate Russian poverty trends in the 1990s, Takeda (2004) concurs, finding that rural poverty is more likely to be persistent and related to hidden unemployment and low skill levels.

In this paper, we add an important strand to the existing literature by taking the rising economic tide as our point of departure and rigorously examining poverty trends across different settlement types. Importantly, our investigation of poverty dynamics uses more

\footnotetext{
1 See, for example, Ovtcharova (2001), Zubarevich (2003), Spryskov (2003).

${ }^{2}$ Urban bias theory has typically been considered in the context of developing economies and argues that states further urban interests at the expense of rural areas by diverting resources in a manner favourable to urban dwellers (Lipton, 1976).
} 


\section{'Ruralisation' of poverty in Russia}

recent data than previously and covers a period of sustained economic growth, adding credibility to our findings.

We find that urban poverty declines at twice the rate of rural poverty so that by 2004 poverty in Russia had become a largely rural phenomenon for the first time since transition began. This finding does not stem from changing population characteristics or shares, is not dependent on the use of a particular poverty line nor is it driven by the rapid expansions that have occurred in Moscow, St Petersburg or other urban areas. Our findings flesh out those of Ravallion et al. (2007) who, in contrast to other regions, 'find signs' of a ruralisation of poverty in the transition economies. We are able to attribute some of the differential to the labour market.

Understanding the different dynamics of rural and urban poverty is crucial if Russia is to develop evenly and avoid policies of 'urban bias' associated with embedded pockets of poverty and social exclusion. The answers to these questions are crucial both for the design of policy as well as for understanding the immediate prospects of the poor and the nature of Russia's economic development.

We proceed as follows. Section 2 introduces the data and describes our empirical approach. Section 3 presents our probit estimations, while Section 4 concludes.

\section{Data and analytical framework}

Our data is drawn from rounds 9-13 (2000-2004) of the RLMS, a series of household surveys across the Russian Federation aiming to be representative of the population. As such, the RLMS provides comprehensive information on a range of socio-economic and demographic variables. The Appendix provides full descriptive statistics for our data on a range of individual and household characteristics such as settlement type, gender, age category, marital status, education, occupation and number of children. Our full unbalanced panel contains observations on 53,970 individuals.

Our (main) measure of poverty is constructed (by the RLMS) on the basis of a representative regional subsistence food basket, for a number of distinct demographic groups, adjusted for regional price variations. In constructing a household poverty line, the individual poverty lines are summed across the household and adjusted according to the demographic profile of the household. ${ }^{1}$ If the whole household falls below the poverty line, regardless of any one individual's income the entire household is classified as being 'poor'. Total household income is defined as the sum of the wage received in all types of employment plus the sum of the value of non-cash payments from all types of employment plus the value of consumed or sold home production plus any income received from government benefits, capital and assets and informal gifts from friends/relatives or charitable organisations. This measure is intended to capture the value of a households 'total resource based income' and to this end reflects wellbeing in terms of ability to survive.

More formally,

$$
\text { Total hh income }=\sum_{\mathrm{j}=1}^{\mathrm{n}^{\mathrm{h}}} \sum_{\mathrm{k}=1}^{\mathrm{k}} \mathrm{x}_{\mathrm{jkt}}^{\mathrm{h}}
$$

\footnotetext{
1 To allow for economies of scale, the household poverty line is adjusted according to household size. The adjustment is as follows: sum of the individual poverty lines multiplied by 1 if (household size) $=1$; by 0.9 if $=$ 2 ; by 0.82 if $=3$; by 0.76 if $=4$; by 0.72 if $=5$; by 0.69 if $=6$; by 0.68 if $\geq 7$. To allow for the different demographic profiles of households the poverty lines themselves are subject to demographic adjustment.
} 
Table 1. Poverty rates and composition by population sub group in 2000 and 2004

Elderly (females/males)

Household type

$1+$ elderly only

1 adult of working age only

1 adult of working age and $1+$ elderly

1 adult of working age and $1+$ child

1 adult of working age and $1+$

elderly and $1+$ child

2 adults of working age only

2 adults of working age and $1+$ elderly

2 adults of working age and $1+$ child

2 adults of working age and $1+$

elderly and $1+$ child
Poverty rate \% Change in by sub group poverty rate

$2000 \quad 2004 \quad 2000 / 04$

$30.5 \quad 10.1$

$26.4 \quad 5.6$

$39.3 \quad 20.7$

$-66.8$

$-78.6$

Working age $32.8 \quad 11.1$

$\begin{array}{ll}33.7 & 10.9\end{array}$

$-66.2$

$-67.7$

Elderly

$\begin{array}{rr}8.9 & 1.9 \\ 16.3 & 3.8\end{array}$

$-79.2$

$<16$

$16-29$

30-39

$40-49$

$39.9 \quad 15.0$

$33.2 \quad 10.8$

$-62.3$

$\begin{array}{ll}37.8 & 11.7\end{array}$

$31.8 \quad 11.0$

(

$28.1 \quad 10.0$

$-67.4$

-69.0
-65.5

$-64.4$

$-76.8$

$\begin{array}{lll}5.5 & 1.4 & -74.5\end{array}$

$35.4 \quad 22.8$

$27.4 \quad 5.5$

$\begin{array}{ll}50.5 & 23.7\end{array}$

$-35.6$

$-79.8$

$-53.0$

$\begin{array}{lll}35.5 & 9.3 & -73.7\end{array}$

$\begin{array}{ll}26.5 & 7.8\end{array}$

$-70.4$

$20.3 \quad 7.4$

$37.9 \quad 13.6$

$30.8 \quad 6.7$
$\%$ Individuals

in poverty

$2000 \quad 2004 \quad 2000 / 2004$

$100.0 \quad 100.0$

$\begin{array}{ll}59.2 & 38.5 \\ 40.8 & 59.0\end{array}$

$\begin{array}{ll}29.4 & 32.2 \\ 33.5 & 33.4\end{array}$

2.0

$\%$ Population

shares by

sub group

Change in

poverty rate

with constan

population share

$2000 \quad 2004 \quad 2000 / 04$

0.0

$100.0 \quad 100.0$

$\mathrm{n} / \mathrm{a}$

$-20.7$

$\begin{array}{ll}68.4 \quad 69.0 \\ 31.6 & 28.8\end{array}$

$-21.4$

21.4$$
2.7
$$

$-0.1$

$-0.9$

$\begin{array}{ll}27.4 & 29.4 \\ 30.3 & 31.0\end{array}$

0.6

$-0.9$

$-0.7$

$-2.4$

\section{$\begin{array}{ll}27.2 & 27.7\end{array}$}

$23.8 \quad 24.8$

$-2.2$

$14.8 \quad 15.1$

3.3

$-0.3$

$-1.1$

0.7

0.5

$-2.9$

$-0.5$

2.0

$-1.9$

2.8

$-0.7$

$-1.3$

0.3

3.3

$-4.0$ 
Labour market status

In work

$\begin{array}{lll}23.0 & 5.2 & -77.3\end{array}$

$\begin{array}{lll}38.8 & 20.6 & -46.8\end{array}$

22.5

22.5

18.3

$-4.2$

$\begin{array}{rr}29.8 & 35.3 \\ 9.8 & 4.2\end{array}$

$-7.7$

Low paid

$\begin{array}{lll}49.7 & 25.6 & -48.5\end{array}$

$12.8 \quad 19.3$

$-4.0$

$\begin{array}{ll}9.8 & 4.2 \\ 7.8 & 7.6\end{array}$

6.4

Not in labour market

$\begin{array}{ll}42.0 & 16.2\end{array}$

$-61.5$

$27.7 \quad 28.0$

0.3

$20.1 \quad 17.5$

7.0
3.9

Human capital ${ }^{b}$

Highest educational qualification

University under- or postgraduate

$\begin{array}{lll}18.9 & 4.3 \quad-77.4\end{array}$

$\begin{array}{lll}6.3 & 2.5 & -3.8\end{array}$

$\begin{array}{ll}10.2 & 5.8 \\ 14.8 & 9.5\end{array}$

$-1.9$

$\begin{array}{lll}30.4 & 9.2 & -69.9\end{array}$

$\begin{array}{ll}14.7 & 8.6\end{array}$

-3.8
-6.2
6.3

$22.8 \quad 32.1$

$-1.3$

Complete high school

$\begin{array}{ll}37.3 & 10.8\end{array}$

$-71.1$

$\begin{array}{rrr}28.0 & 34.3 & 6.3\end{array}$

$\begin{array}{rr}22.8 & 32.1 \\ 6.3 & 3.1 \\ 3.6 & 10.0\end{array}$

$-3.3$

47.215

$-58.3$

$8.3 \quad 5.1$

$-3.2$

$3.6 \quad 10.0$

0.1

Occupation

Managerial/Professional

$21.8 \quad 5.1 \quad-76.7$

$10.2 \quad 7.8$

$-2.4$

$\begin{array}{rr}14.2 & 15.4 \\ 6.3 & 6.9\end{array}$

$-3.1$

$\begin{array}{lll}30.3 & 6.2 & -79.4\end{array}$

$\begin{array}{lll}30.2 & 8.9 & -70.5\end{array}$

Manual

$46.6 \quad 15.0$

$-67.7$

$\begin{array}{rr}6.2 & 4.2 \\ 13.1 & 12.4\end{array}$

$-2.0$

$-0.7$

$13.2 \quad 14.1$

$-2.4$

Unskilled

Observations $^{c}$

Notes:

${ }^{a}$ Absolute change in previous two columns.

${ }^{b}$ Values are set to 0 if not in working age population.

${ }^{c}$ Number of observations $2000=9713,2004=11195$. 


\section{6 of 15 C. J. Gerry, E. Nivorozhkin and J. A. Rigg}

where there are $h$ households with $j=1,2 \ldots \mathrm{n}^{\mathrm{h}}$ individuals holding income resource from $\mathrm{x}_{j k t}{ }^{\mathrm{h}}$ sources where $k=1,2, \ldots, \mathrm{K}$ summed over RLMS rounds, $t, 9-13$ and

$$
\text { The hh poverty line }=\left[\sum_{j=1}^{n^{h}} s_{j t} s_{t}\right] \cdot a
$$

where $s$ is a regionally and demographically representative subsistence food basket and $a$ is the chosen equivalising factor detailed in footnote 1 .

In the event that the figure from equation (1) is less than that generated by equation (2) then the individuals within that household are defined as being in poverty for that period. Note that an individual's poverty status depends on household cash and non-cash income as well as on household demographics. Thus, an individual can fall into poverty between time $t$ and $t+1$ due to changes in the cash or non-cash income of other household members or through changes in the demographic make up of the household and regardless of fluctuations in his/her own personal income. The grounds for this are straightforward and well known. The vast majority of individuals reside together in household units in which they share their pooled resources.

\section{Results}

\subsection{Cross-sectional poverty}

Using our RLMS data we first seek to unravel the steep fall in poverty between 2000 and 2004 (Table 1). In keeping with the World Bank (2005) findings, the overall poverty incidence in our data fell by $66.8 \%$, from $30.5 \%$ to $10.1 \%$ during this period. At first blush Table 1 suggests that the improving living standards associated with Russian economic recovery have been shared across the population. Russia's rising tide does appear to have lifted all boats. Indeed, the first two columns of Table 1 show that, irrespective of whether we divide the population according to gender, age, human capital, labour market status or household type, all sub-groups have enjoyed a sharp decline in poverty. However, the decline has been far from uniform. The population sub-groups to benefit the least are those in rural areas $(47.3 \%$ decline), in single adult households with $(53 \%)$ or without $(35.6 \%)$ children and those without work $(48.5 \%)$ or in low paid work $(46.8 \%)$. The results pertaining to individual age and household type confirm the improving relative living standards of the elderly, ${ }^{1}$ while it is also clear that the labour market plays an important role in poverty reduction with the unemployed, the inactive and the low-paid all experiencing lower poverty declines. The most striking contrast, however, is between those in urban areas, where poverty declined by $78.6 \%$, and those in rural areas where poverty only fell by $47.3 \%$.

The importance of this last observation is borne out in columns 4,5 and 6 of Table 1 , which examine the extent to which the non-uniform pattern of poverty reduction has given rise to a change in the composition of the poor. In contrast to the findings of the World Bank (2005), that the 'majority of the poor live in urban areas' we find that, besides experiencing a higher poverty incidence, by 2004 the rural population accounted for over half of those in poverty, an increase of 18.2 percentage points. This result is in line with Ravallion et al. (2007) who, in contrast to other regions, 'find signs' (p. 27) of the ruralisation of poverty in Eastern Europe and the former Soviet Union. According to our results, also increasing their representation among the poor are those without work and those with high school or less education. Of course, the figures in column 6 may simply reflect changes in population shares rather than unequal improvements in poverty rates. To guard against this, columns 7 and 8 record the population shares of the sub-groups while

\footnotetext{
1 The age-poverty profile results are robust to alternative methods of equivalising household income.
} 


\section{'Ruralisation' of poverty in Russia}

column 9 calculates the change in poverty share that would have occurred if the population share had remained constant. It becomes clear that the increased representation of rural households among the poor has not occurred as a result of shifting population patterns-in fact, had the population share remained constant, the rural poverty share would have increased still further. For the labour market, the non-uniform poverty reduction is also borne out since the decline in share of the working poor would have been even greater had the numbers in work (unemployed/out of labour force) not increased (decreased). Similarly, had there not been a substantial fall in the proportion of individuals in receipt of low pay, this group would have represented a considerably higher proportion of those in poverty. ${ }^{1}$

\subsection{Rural poverty}

The previous section presented evidence both that economic growth in Russia at the start of the present century produced substantial declines in poverty among all population sub-groups but also that a growing 'divide' is emerging between those in rural and urban areas. It would seem that Russia's economic development has produced an urban bias, which in turn sees the nature of Russian poverty acquiring an increasingly rural hue. Commenting on the emergence of the 'new poor' a decade ago, McAuley (1995) observed that they have 'much the same stock of human capital' and that 'in principle, therefore, it should be relatively easy to transform them back into non-poor' (McAuley, 1995, p. 188). A decade on it would appear that there might be an excluded rural sub-group unable to benefit from the rising tide of economic growth. There are a number of reasons why this might be so but understanding why certain groups are not being 'transformed back into non-poor' is clearly essential. Rural dwellers have been faced with fewer economic opportunities, have faced restrictions in land use, have been neglected in relation to oil, gas and ore rich areas, have been surrounded by a decaying rural infrastructure and have seen the brightest human capital migrate to more rewarding urban pastures.

In the remainder of this paper we delve deeper into the reasons underpinning the growing rural-urban divide. We will demonstrate that the more modest decline in rural poverty is highly significant and does not derive from changing population characteristics any more than it is a result of changing population shares.

When thinking about poverty in the rural context it is natural to think that the differential in incidence at any point in time might be accounted for by area distinct population characteristics. To investigate the extent to which the observed rural-urban point-in-time poverty rates can be explained by 'standard' observable characteristics we pool our five waves of data and estimate a series of poverty regressions, as reported in Table $2 .^{2}$ Model 1 confirms that rural poverty rates are 15.5 percentage points higher than in urban areas. ${ }^{3}$ Model 2 , through the addition of controls for age, marital status, household size and structure, education and time sees this gap reduce marginally to 13.2 percentage points. In other words, a comprehensive set of observable household and individual characteristics explain only around a seventh of the bivariate point-in-time differences in the incidence of poverty between rural and urban areas.

\footnotetext{
${ }^{1}$ Interestingly, the greater representation of the less educated among the poor comes about through their increased representation in the sample.

${ }^{2}$ In these regressions we obtain robust standard errors through clustering to control for the fact that we have observations on individuals in the same household over time.

3 Throughout this analysis we include only those observations clearly classified as 'rural' or 'urban'. There are a small percentage of households that the RLMS classifies as 'rural non-agricultural' but it is not clear a priori whether these are a distinct category or should be judged on a case-by-case basis. In any event, their inclusion or otherwise does not affect our main findings.
} 
Table 2. Poverty regressions

\begin{tabular}{|c|c|c|c|c|c|c|c|}
\hline & Model 1 & Model 2 & Model 3 & Model 4 & Model 5 & Model $6^{\mathrm{a}}$ & Model $7^{\mathrm{b}}$ \\
\hline \multicolumn{8}{|l|}{ Area type } \\
\hline \multirow[t]{2}{*}{ Rural } & $0.155^{\star \star \star}$ & $0.1320^{\star \star \star}$ & $0.1320^{\star \star \star}$ & $0.0506^{\star \star \star}$ & $0.0355^{\star \star \star}$ & $0.0572^{\star \star \star}$ & $0.0232^{\star \star}$ \\
\hline & 0.0055 & 0.0053 & 0.0053 & 0.0082 & 0.0083 & 0.0118 & 0.0099 \\
\hline \multicolumn{8}{|l|}{ Gender } \\
\hline \multirow[t]{2}{*}{ Female } & & 0.0039 & 0.0039 & 0.0040 & 0.0044 & 0.0068 & $0.0126^{\star \star}$ \\
\hline & & 0.0042 & 0.0042 & 0.0042 & 0.0041 & 0.0057 & 0.0056 \\
\hline \multicolumn{8}{|l|}{ Individual age } \\
\hline \multirow[t]{2}{*}{ 30-39 } & & $0.0294^{\star \star \star}$ & $0.0293^{\star \star \star}$ & $0.0299^{\star \star \star}$ & $0.0326^{\star \star \star}$ & $0.0200^{\star \star}$ & \\
\hline & & 0.0072 & 0.0072 & 0.0072 & 0.0072 & 0.0077 & \\
\hline \multirow[t]{2}{*}{$40-49$} & & $0.0475^{\star \star \star}$ & $0.0471^{\star \star \star}$ & $0.0474^{\star \star \star}$ & $0.0500^{\star \star \star}$ & $0.0416^{\star \star \star}$ & \\
\hline & & 0.0078 & 0.0078 & 0.0078 & 0.0078 & 0.0082 & \\
\hline \multirow[t]{2}{*}{ 50-54/59 (female/male) } & & $0.0499^{\star \star \star}$ & $0.0496^{\star \star \star}$ & $0.0498^{\star \star \star}$ & $0.0548^{\star \star \star}$ & $0.0393^{\star \star \star}$ & \\
\hline & & 0.0100 & 0.0100 & 0.0100 & 0.0100 & 0.00106 & \\
\hline \multirow[t]{2}{*}{$55+/ 60+($ female $/$ male $)$} & & $-0.0997^{\star \star \star}$ & $-0.998^{\star \star \star}$ & $-0.0984^{\star \star \star}$ & $-0.0943^{\star \star \star}$ & & \\
\hline & & 0.0051 & 0.0051 & 0.0051 & 0.0051 & & \\
\hline \multicolumn{8}{|l|}{ Marital status } \\
\hline \multirow[t]{2}{*}{ Married } & & $-0.0705^{\star \star \star}$ & $-0.0703^{\star \star \star}$ & $-0.0701^{\star \star \star}$ & $-0.0696^{\star \star \star}$ & $-0.0707^{\star \star \star}$ & $-0.0414^{\star \star \star}$ \\
\hline & & 0.0070 & 0.0070 & 0.0070 & 0.0069 & 0.0087 & 0.0116 \\
\hline \multirow[t]{2}{*}{ Cohabiting } & & $0.0216^{\star \star}$ & $0.0214^{\star \star}$ & $0.0217^{\star \star}$ & $0.0204^{\star \star}$ & 0.0126 & -0.0049 \\
\hline & & 0.0074 & 0.0074 & 0.0074 & 0.0073 & 0.0086 & 0.0115 \\
\hline \multicolumn{8}{|l|}{ Number of children } \\
\hline \multirow[t]{2}{*}{ Aged $<7$ years } & & $0.0758^{\star \star \star}$ & $0.0758^{\star \star \star}$ & $0.0751^{\star \star \star}$ & $0.0718^{\star \star \star}$ & $0.05953^{\star \star \star}$ & $0.0145^{\star \star}$ \\
\hline & & 0.0042 & 0.0042 & 0.0042 & 0.0041 & 0.0058 & 0.0064 \\
\hline \multirow[t]{2}{*}{ Aged $7-18$ years } & & $0.0696^{\star \star \star}$ & $0.0697^{\star \star \star}$ & $0.0690^{\star \star \star}$ & $0.0669^{\star \star \star}$ & $0.0830^{\star \star \star}$ & $0.0157^{\star \star}$ \\
\hline & & 0.0033 & 0.0033 & 0.0033 & 0.0032 & 0.0043 & 0.0050 \\
\hline \multirow[t]{2}{*}{ Total household size } & & $-0.0223^{\star \star \star}$ & $-0.0224^{\star \star \star}$ & $-0.0222^{\star \star \star}$ & $-0.0205^{\star \star \star}$ & $-0.0342^{\star \star \star}$ & $0.0107^{\star \star \star}$ \\
\hline & & $(0.0021)$ & $(0.0021)$ & $(0.0020)$ & $(0.0020)$ & $(0.0028)$ & $(0.0021)$ \\
\hline \multicolumn{8}{|c|}{ Highest educational achievement } \\
\hline \multirow[t]{2}{*}{ University } & & $-0.0768^{\star \star \star}$ & $-0.0763^{\star \star \star}$ & $-0.0776^{\star \star \star}$ & $-0.0792^{\star \star \star}$ & $-0.1211^{\star \star \star}$ & $-0.0242^{\star \star}$ \\
\hline & & 0.0061 & 0.0061 & 0.0060 & 0.0059 & 0.0071 & 0.0060 \\
\hline \multirow[t]{2}{*}{ Technical qualification } & & $-0.0304^{\star \star \star}$ & $-0.0298^{\star \star \star}$ & $-0.0310^{\star \star \star}$ & $-0.0371^{\star \star \star}$ & $-0.0739^{\star \star \star}$ & $-0.0120^{\star}$ \\
\hline & & 0.0067 & 0.0067 & 0.0066 & 0.0064 & 0.0084 & 0.0063 \\
\hline
\end{tabular}




\section{Completed high school}

Incomplete high school + base

Year

2001

2002

2003

2004

Year (continuous)

Interaction term

Rural`year

Moscow and St Petersburg

Big city

Observations

53,970

53,970

53,970

$-0.0478^{\star \star \star}$

0.0011
$-0.0571^{\star \star \star}$
0.0014

$-0.0556^{\star \star \star}$

0.0014

$-0.0643^{\star \star \star}$

$-0.0251^{\star \star \star}$

$0.0246^{\star \star \star}$

0.0022

$0.0233^{\star \star \star}$

0.0022

$-0.0787^{\star \star \star}$

0.0054

$-0.0218^{\star \star \star}$

(0.0022)
0.0019

0.0019

$0.0259^{\star \star \star}$

0.0032

$0.0089^{\star \star}$

0.0028

Notes:

${ }^{\text {a }}$ Estimated on sample of working age only.

${ }^{\mathrm{b}}$ Estimated on sample of elderly only.

Absolute value of $\mathrm{z}$ statistics in parentheses.

${ }^{\star}$ Significant at $10 \%$;

${ }^{\star \star}$ significant at $5 \%$;

$\star \star \star$ significant at $1 \%$. 


\section{0 of 15 C. J. Gerry, E. Nivorozhkin and J. A. Rigg}

\subsection{The growing rural-urban divide}

The increasing rural complexion of poverty is captured in Figure 1, which shows the sharp rise in the proportion of poor people living in rural areas. The rural poverty share increased appreciably in every year between 2000 and 2004 though the largest rise occurred between 2002 and 2003. The graph also illustrates the decline in the ratio of the rural poverty rate as a percentage of the urban poverty rate, the key behind the rise to the changes in poverty shares. The poverty rate in urban areas was some two-thirds of the level in urban areas in 2000; by 2004 it had fallen to below a third.

Having established that the point-in-time differential in rural-urban poverty rates does not stem from differences in population characteristics, we might also ask whether the non-uniform decline over time is associated with changing population characteristics. Once again we find that the steeper urban decline in poverty is highly significant and is not the result of changing population characteristics. Results (Model 4 in Table 2) from a probit regression of poverty on rural status, a set of 'standard' (time-varying) characteristics, a linear time trend and a ruraltime trend interaction term, reveal a significant, positive marginal effect of the interaction term of 2.5 percentage points. The marginal effect on the time trend itself is -5.7 percentage points, thus, the reduction in poverty over time in rural areas is around half of that in urban areas. Notwithstanding this there are two dimensions not explicitly captured in our analysis so far that merit further investigation if we wish to unravel the rural-urban poverty divergence.

First, it is possible that the increase in the rural-urban poverty gap observed at the national level could be driven by the rapid economic expansion that has occurred over this period either in Moscow and St Petersburg, as the two big 'European' cities, or in 'large' cities more generally. In Table 3 we disaggregate our analysis in order to isolate the city size effect. ${ }^{1}$ We find that the proportionate poverty reduction across all urban areas is broadly similar and substantially higher than the aggregate rate. The sharpest decline $(85.4 \%)$ was observed in Moscow/St Petersburg but the overall impact of this on the composition of the poor in Russia and on the growth in rural-urban poverty differentials is negligible, since poverty among individuals in Moscow/St Petersburg accounts for less than $5 \%$ of total poverty. This finding is supported in Model 5 in Table 2, in which we include these city size control variables. Doing so only reduces the rural-time trend interaction term by around a tenth of one percentage point. That is, even when we extract large cities from the reference group, the rural-urban poverty gap remains almost as large.

Second, our own evidence (Table 1), as well as that presented in earlier literature, ${ }^{2}$ is suggestive of the important role played by the labour market in preserving and improving living standards. This being so it is possible that the growth in the rural-urban poverty gap may actually reflect differences in each area's respective labour markets. That is, the aggregate effect may be generated purely by individuals of working-age rather than being a universal phenomenon. If this is the case then it is entirely possible that elderly individuals in rural areas may not have fallen behind their urban counterparts. ${ }^{3}$ Referring

\footnotetext{
${ }^{1}$ Large cities are defined here as those of over 500,000 people. We experiment with various definitions and the results are qualitatively similar.

${ }^{2}$ See, for example, Clarke (2002), Gerry and Li (2007).

3 To the extent that the elderly are reliant on state support and that changes in the levels of such support are correlated across regions we might expect this to be the case. The political importance of this population group goes someway to understanding their improved living standards relative to the population. However, even if the growing poverty disparities were generated by labour market factors, we would not expect the elderly to be entirely immune from these changes since (i) many of them engage in some form of paid work and (ii) many live with at least one person of working age and since income is measured at the household level, elderly incomes are impacted through the labour market activity of others in the household.
} 


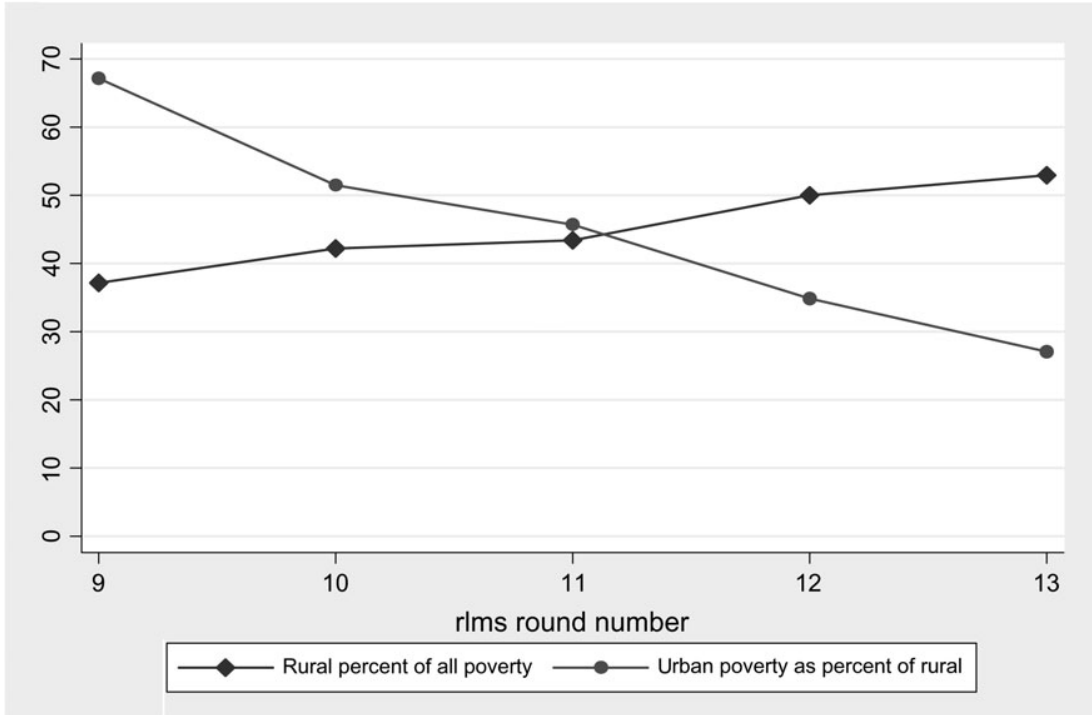

Fig. 1. Poverty rates and poverty shares by area type: 2000-2004.

to the lower half of Table 3 our suspicions are, in part, confirmed. Poverty among individuals of working-age in rural areas fell by $48.1 \%$ compared to the far greater reduction of $77.8 \%$ for working-age individuals in urban areas. Among the elderly, the urban decline was again greater $(85.9 \%$ compared to $64.1 \%)$ but the difference in the extent of poverty reduction was closer than for working-age individuals. This is further supported in our final probit regressions (Models 6 and 7 in Table 2), which estimate the rural-time trend coefficient for working age and elderly individuals separately. These regressions imply a somewhat smaller 'elderly' slope coefficient (0.9\% compared to $2.6 \%)$ from the rural-time trend interaction term. Nevertheless, the interaction term remains highly significant. This is an important finding in that it highlights that the growth in the rural-urban poverty differential was concentrated primarily, if not exclusively, among the working age population. The final column of Table 2 suggests that part of the explanation for the lower/higher poverty rates for urban/rural working-age individuals is to be found in the changing population shares. However, even based on the final column, the share of poverty accounted for by working-age individuals in rural areas increased by $13.6 \%$, while it remained virtually unchanged for the rural elderly.

A concern with any poverty analysis of this sort relates to the choice of the poverty line itself. The selection of any particular poverty line is open to the criticism of being arbitrary so we investigate the trends illustrated by Figure 1 for six alternative specifications and find them to be robust to the choice made (see Table 4). Initially, we selected three additional poverty lines based on less than half, 1.5 and 2 times the official poverty line. In each case, the rural poverty share increased notably between 2000 and 2004, by 21.0 percentage points when the most severe poverty threshold of less than 0.5 was employed, and by 10.6 percentage points for the most generous poverty threshold of 2 times the official threshold. This indicates that the growth in rural-urban poverty differences was more marked for more severe indicators of poverty. ${ }^{1}$ Using a conceptually distinct measure of poverty, based

1 This supports Takeda (2004) who found that poverty was more persistent and severe in rural areas. 
Table 3. Poverty rates and composition by rural/urban population sub groups in 2000 and 2004

\begin{tabular}{|c|c|c|c|c|c|c|c|c|c|}
\hline & \multicolumn{2}{|c|}{ Poverty rate } & \multirow{2}{*}{$\begin{array}{l}\% \text { Change in } \\
\text { poverty rate } \\
2000 / 04\end{array}$} & \multicolumn{2}{|c|}{$\begin{array}{l}\% \text { Individuals in poverty } \\
\text { by sub group }\end{array}$} & \multirow{2}{*}{$\begin{array}{l}\text { Change in } \\
\text { poverty share } \\
2000 / 04\end{array}$} & \multicolumn{2}{|c|}{$\begin{array}{l}\% \text { Population shares } \\
\text { by sub group }\end{array}$} & \multirow{2}{*}{$\begin{array}{l}\% \text { In poverty } \\
2004 \text { with } \\
\text { population share } \\
\text { in } 2000\end{array}$} \\
\hline & 2000 & 2004 & & 2000 & 2004 & & 2000 & 2004 & \\
\hline \multicolumn{10}{|l|}{ Sub group by region } \\
\hline Moscow and St Petersburg & 18.4 & 2.7 & -85.4 & 2.9 & 3.6 & 0.7 & 4.9 & 13.6 & -1.7 \\
\hline Large cities ${ }^{\mathrm{b}}$. & 24.3 & 5.6 & -77.1 & 20.8 & 12.5 & -8.4 & 26.1 & 22.6 & -6.1 \\
\hline Small urban ${ }^{\mathrm{c}}$. & 28.9 & 7.2 & -75.1 & 35.5 & 24.9 & -10.5 & 37.4 & 35.0 & -8.6 \\
\hline Rural & 39.3 & 20.7 & -47.3 & 40.8 & 59.0 & 18.2 & 31.6 & 28.8 & 21.4 \\
\hline \multicolumn{10}{|l|}{ Sub group by working age } \\
\hline Urban working age & 28.8 & 6.4 & -77.8 & 38.2 & 26.9 & -11.3 & 40.5 & 42.6 & -13.0 \\
\hline Rural working age & 43.8 & 22.7 & -48.1 & 24.7 & 37.5 & 12.7 & 17.2 & 16.7 & 13.6 \\
\hline Urban elderly & 11.2 & 1.6 & -85.9 & 5.2 & 2.2 & -3.0 & 14.3 & 14.2 & -3.0 \\
\hline Rural elderly & 19.5 & 7.0 & -64.1 & 4.6 & 4.2 & -0.4 & 7.2 & 6.1 & 0.4 \\
\hline
\end{tabular}

Notes:

${ }^{a}$ Absolute change in previous two columns.

${ }^{\mathrm{b}}$ Cities of over 500,000 excluding Moscow and St Petersburg.

${ }^{\mathrm{c}}$ Urban conurbations of less than 500,000

Number of observations: $2000=9,713,2004=11,195$ 
Table 4. Breakdown of poverty by rural status 2000 and 2004, various poverty lines

\begin{tabular}{|c|c|c|c|}
\hline \multirow[b]{2}{*}{ Poverty line } & \multicolumn{2}{|c|}{ Year } & \multirow{2}{*}{$\begin{array}{l}\text { Percent change } \\
2000 / 2004\end{array}$} \\
\hline & 2000 & 2004 & \\
\hline \multicolumn{4}{|l|}{ Less than $0.5^{\star}$ official poverty line } \\
\hline Poverty rate & 10.1 & 2.9 & -71.3 \\
\hline Percent of all poor in rural areas & 46.6 & 67.6 & 45.1 \\
\hline \multicolumn{4}{|l|}{ Official poverty line } \\
\hline Poverty rate & 30.5 & 10.1 & -66.9 \\
\hline Percent of all poor in rural areas & 40.8 & 60.5 & 48.3 \\
\hline \multicolumn{4}{|l|}{ Less than $1.5^{\star}$ official poverty line } \\
\hline Poverty rate & 51.1 & 20.8 & -59.3 \\
\hline Percent of all poor in rural areas & 36.7 & 51.2 & 39.5 \\
\hline \multicolumn{4}{|l|}{ Less than $2.0^{\star}$ official poverty line } \\
\hline Poverty rate & 68.5 & 34.1 & -50.2 \\
\hline Percent of all poor in rural areas & 32.8 & 43.4 & 32.3 \\
\hline \multicolumn{4}{|c|}{ Lowest quintile of contemporaneous income ${ }^{\mathrm{a}}$} \\
\hline Poverty rate & 20.0 & 20.0 & $\mathrm{n} / \mathrm{a}$ \\
\hline Percent of all poor in rural areas & 41.5 & 54.5 & 31.3 \\
\hline \multicolumn{4}{|c|}{ Lowest two quintiles of contemporaneous income $e^{\mathrm{a}}$} \\
\hline Poverty rate & 40.0 & 40.0 & $\mathrm{n} / \mathrm{a}$ \\
\hline Percent of all poor in rural areas & & & \\
\hline
\end{tabular}

Note.

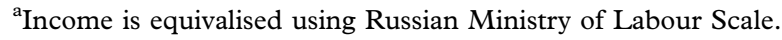

on contemporaneous, relative income and a different equivalence scale further persuades us as to the robustness of our claims. Using two income cut-offs - the lowest quintile and the two lowest quintiles - of wave-specific household equivalised income, ${ }^{1}$ we confirm that the more gradual decline in poverty in rural compared to urban areas is a 'genuine' phenomenon and not an artefact of the choice of a particular poverty line.

\section{Discussion and conclusions}

During Russia's euphemistically named transition there has been a plethora of research into the nature and causes of poverty. As transition has evolved into development, the focus has switched somewhat into matters pertaining to economic growth and, to the extent that poverty has held the attention (World Bank, 2005), it has been through jointly documenting its decline and noting its persistence in certain areas. In this paper, we take the substantial post-1998 reduction in poverty as our point of departure and focus our gaze on the changing relative distribution of poverty. Aside from issues of economic efficiency, this is important from a social justice perspective since, if not all population sub-groups benefit from economic growth, policy interventions may be justified and necessary.

Our data establish both that a substantial aggregate fall in poverty incidence has occurred (from $31.1 \%$ in 2000 to $10.6 \%$ in 2004 ) and that the effect of the fall has been felt broadly across socio-economic groups. Nevertheless, not only is $10.6 \%$ indicative of relatively widespread poverty but a closer look at the data demonstrates important

${ }^{1}$ Where income was equivalised using the same scale as adopted by the Russian Ministry for Labour (Braithwaite, 1998). This scale assigns a value of 0.63 to each elderly person in the household and a value of 0.9 for every child. 


\section{4 of 15 C. J. Gerry, E. Nivorozhkin and J. A. Rigg}

elements of unevenness in its impact. In particular, rural, young, unemployed, low paid and poorly educated individuals have been freed from poverty to a much lesser extent. However, we find that the most striking contrast is between those in urban areas, enjoying a $78.6 \%$ decline, and those in rural areas for whom poverty has been reduced by just $47.3 \%$. As a consequence, and in contrast to findings reported elsewhere, we argue that transition has moved on in Russia and that for the first time poverty has become a largely rural phenomena. Indeed, we are pessimistic about the apparent pockets of serious social and economic exclusion that have come to characterise rural Russia.

Investigating the robustness of our rural-urban observations, we establish the following important results. First, observable characteristics explain less than a fifth of the point-intime rural-urban poverty gap and that, controlling for such characteristics, poverty reduction in rural areas proceeds at just half the pace of the decline in urban dwellings. Second, the shallower decline in rural settlements is not a result of either changing population characteristics or changing population shares. Third, the growing rural-urban divergence does not stem from the well-documented 'outliers' that are Moscow and St Petersburg, or from other big cities. Fourth, the growing divergence is primarily, though not exclusively, driven by the working-age population. Finally, the generality of the claim is not dependent on the use of a particular poverty line although experimenting with alternative specifications marks out an even greater divergence when speaking to more severe measures of poverty.

Finally, some caveats regarding our conclusions. In this paper, our focus has been purely on a measure of absolute income poverty and we make no claim to have examined multidimensional aspects of poverty though we acknowledge that this would, no doubt, add great value to the investigation. A fruitful avenue for future research on Russian poverty dynamics involves investigating what drives 'exits' from and 'entries' into poverty. Are the causes of rural and urban poverty the same? Do the routes into and out of poverty operate differently in rural areas? Along with the investigation of the role played by the urban and rural labour markets these questions merit further research.

\section{Bibliography}

Clarke, S. 2002. Making Ends Meet in Contemporary Russia: Secondary Employment, Subsidiary Agriculture and Social Networks, Cheltenham, Edward Elgar

Gerry, C. J. and Li, C. A. 2004. 'Coping with Economic Shocks: Consumption Smoothing and the 1998 Russian Crisis', Working Paper 43, UCL-SSEES Centre for Study of Economic and Social Change in Europe

Gerry, C. J. and Li, C. 2007. Consumption Smoothing and Vulnerability in Russia. William Davidson Institute Working Paper Series (885), pp. 1-39. University of Michigan, US, http:// www.wdi.umich.edu/Publications/WorkingPapers/

Katsiaouni, O. and Gorniak, J. 2001. 'Globalisation and Rural Poverty in Transition Economies', Unpublished paper for meeting of United Nations Division for Social Policy and Development, http://www.un.org/esa/socdev/social/papers/paper_gorkat.pdf

Klugman, J. and Braithwaite, J. 1998. Poverty in Russia: An Overview, World Bank Research Observer, vol. 13:37-58

Lipton, M. 1976. Why Poor People Stay Poor: Urban Bias in World Development, Cambridge, MA: Harvard University Press

McAuley, A. 1995. Inequality and poverty, in Lane, D. (ed.), Russia in Transition: Politics, Privatisation and Inequality, Longman, London and New York, pp. 177-189

Ovcharova, L. and Popova, D. 2001. What kind of Poverty Alleviation Policy does Russia need? Published in Russian Economic Trends, 2001, Quarter 1. Russian European Centre for Economic Policy (RECEP). Moscow, http://www.recep.ru/phase4/pdf\%27s/ret2001q1rfa.pdf

Pickup, F. and White, A. 2003. Livelihoods in postcommunist Russia: urban/rural comparisons, Work, Employment and Society, vol. 17, no. 3, 419-34 


\section{'Ruralisation' of poverty in Russia}

Ravallion, M., Chen, S. and Sangraula, P. 2007. 'New Evidence on the Urbanization of Global Poverty', Development Research Group, World Bank, March

Spryskov, D. 2003. "Below the Poverty Line: Duration of Poverty in Russia," Economics Education and Research Consortium, Moscow. Working Paper Series No 03/04e, http:// 212.24.37.245/details/download.aspx?file_id=3732

Takeda, Y. 2004. 'Transient or chronic poverty in Russia? The urban and rural poor during the 1990s' (in Russian), Working paper no. 309, CIRJE F-Series, University of Tokyo

Wegren, S. K., O’Brien, D. J. and Patsiorkovski, V. V. 2003. Why Russia's rural poor are poor, Post-Soviet Affairs, vol. 19, no. 3, 264-87

World Bank 2005. Russian Federation: Reducing Poverty Through Growth and Social Policy Reform, Poverty Reduction and Economic Management Unit Europe and Central Asia Region, February 8

World Bank 2006. Russian Economic Report, April

Zubarevich, N. 2003. 'Russia: Case study on Human Development Progress Toward the MDGs at the Sub-National Level', Background Paper for HDR 2003. United Nations Development Programme.

\section{Appendix}

Table A.1. Definition of variables and descriptive statistics. Full sample $(n=57,616)$

\begin{tabular}{|c|c|c|c|}
\hline Variable & Definition & Mean & $\begin{array}{l}\text { Standard } \\
\text { deviation }\end{array}$ \\
\hline \multicolumn{4}{|l|}{ Full sample $(n=57,616)$} \\
\hline Urban & Household lives in urban area & 0.65 & 0.48 \\
\hline Rural & $\begin{array}{l}\text { Household lives in rural agricultural } \\
\text { area }\end{array}$ & 0.28 & 0.45 \\
\hline Female & Gender & 0.55 & 0.50 \\
\hline Age $<16$ & Age less than 16 & 0.20 & 0.40 \\
\hline Aged 16-29 & Age between 16 and 29 & 0.23 & 0.42 \\
\hline Aged 30-39 & Age between 30 and 39 & 0.14 & 0.34 \\
\hline Aged $40-49$ & Age between 40 and 49 & 0.15 & 0.36 \\
\hline $\begin{array}{l}\text { Aged } 50-54 / 59 \\
\quad \text { (females/males) }\end{array}$ & $\begin{array}{l}\text { Age between } 50 \text { and retirement age } \\
\text { ( } 55 \text { for females/ } 60 \text { for males) }\end{array}$ & 0.08 & 0.27 \\
\hline Elderly & Of retirement age $(55+/ 60+)$ & 0.21 & 0.41 \\
\hline Cohabiting union & Married or living together & 0.50 & 0.50 \\
\hline $\begin{array}{l}\text { Number of households } \\
\text { children } \leq 7\end{array}$ & Number of young children & 0.31 & 0.58 \\
\hline $\begin{array}{l}\text { Number of households } \\
\text { children }>7\end{array}$ & Number of older children & 0.65 & 0.84 \\
\hline University education & $\begin{array}{l}\text { Undergraduate university education } \\
\text { or higher }\end{array}$ & 0.10 & 0.31 \\
\hline Technical and medical & Technical and medical school & 0.15 & 0.36 \\
\hline High school & Completed high school (11 years) & 0.32 & 0.47 \\
\hline Vocational & $\begin{array}{l}\text { Vocational training (PTU, } \\
\text { FZU, FZO) }\end{array}$ & 0.08 & 0.27 \\
\hline Incomplete high school only & Incomplete high school (8 years) & 0.34 & 0.47 \\
\hline Managerial and Professional & $\begin{array}{l}\text { Legislator, Senior Manager/Official/ } \\
\text { Technician, professional }\end{array}$ & 0.16 & 0.37 \\
\hline Non-manual & $\begin{array}{l}\text { Clerks, service workers and market } \\
\text { workers }\end{array}$ & 0.07 & 0.25 \\
\hline Manual & $\begin{array}{l}\text { Agriculture/fisheries, plant \& } \\
\text { machine operators, crafts/trades }\end{array}$ & 0.14 & 0.34 \\
\hline Unskilled & Unskilled occupations & 0.05 & 0.22 \\
\hline Household (real) income & Total real household income & 8548 & 13072 \\
\hline
\end{tabular}

from all sources 